\section{Sharīah governance and agency dynamics of Islamic banking operations in the Kingdom of Saudi Arabia}

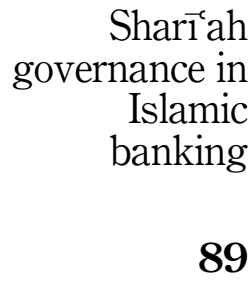

Abul Hassan

Centre of Research Excellence for Islamic Banking and Finance, King Fahd University of Petroleum and Minerals, Dhahran, Saudi Arabia

M. Sadiq Sohail

Management and Marketing, King Fahd University of Petroleum and Minerals, Dhahran, Saudi Arabia, and

Md Mahfuzur Rahaman Munshi

School of Accounting and Law, University of Gloucestershire, Cheltenham, UK
Received 7 December 2020 Revised 21 December 2020 21 June 2021

8 September 2021

10 September 2021

28 October 2021

Accepted 30 October 2021

\begin{abstract}
Purpose - This study aims to investigate and point out the variations of agency theory in the context of Shariah governance in Islamic banking operations in the Kingdom of Saudi Arabia (KSA).

Design/methodology/approach - The study followed the approach of quantitative Corporate Governance Index (CGI) by computing the Gov-index (Gompers et al., 2003) and the Gov-score (Brown and Caylor, 2004; Saffieddine, 2009) to examine corporate governance (CG) issues using primary as well as secondary data. The primary data was generated from three full-fledged Islamic banks (IBs) and nine traditional banks with Islamic banking wings, all operating in the KSA. The approach was to provide an insight into the agency structure in the context of Islamic banking, which may lead to a trade-off between the conformity of Shariah (Islamic law) rules and processes followed in safeguarding the rights of investors.

Findings - The majority of the Islamic banking services that are surveyed in this study acknowledge the significance of Shariah governance and have implemented the fundamental methods, in conformity with this system. Certain flaws in Shariah governance principles pertaining to audit, control and transparency are reported.

Practical implications - The research outcomes will be invaluable to IBs aiming to improve existing SG practices. It also has implications for IB managers to design strategies while complying with regulations and to protect the interests of all investors without breaching the ethics of Shariah.

Originality/value - This paper adds original value to the body of knowledge on agency relationship by analysing the dynamics of agency theory in the unique and complex context of Shariah governance of IBs or those offering Islamic products in the KSA. The results can be used as a valuable feedback for improvement of Shariah governance in the banking system in the KSA and the Gulf region at large.
\end{abstract}

Keywords Agency dynamics, Board of directors, Corporate governance, Financial reporting, Islamic banking, Shariah governance

Paper type Research paper

(C) Abul Hassan, M. Sadiq Sohail and Md Mahfuzur Rahaman Munshi. Published in ISRA International Journal of Islamic Finance. Published by Emerald Publishing Limited. This article is published under the Creative Commons Attribution (CC BY 4.0) licence. Anyone may reproduce, distribute, translate and create derivative works of this article (for both commercial and non-commercial purposes), subject to full attribution to the original publication and authors. The full terms of this licence may be seen at http:// creativecommons.org/licences/by/4.0/legalcode

The authors would like to thank the editor and the two anonymous reviewers for their constructive comments on previous versions of the manuscript.

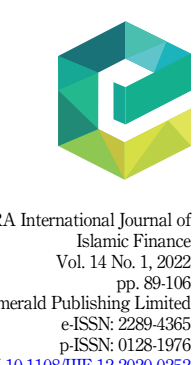

DOI 10.1108/IJIF-12-2020-0252 


\section{Introduction}

Financial institutions become exposed to agency issues when a separation between ownership and control causes senior executives to prioritise their own interests over those of shareholders (Fama and Jensen, 1983). Any potential conflict of interest that may arise should be looked into, eliminated and managed appropriately. Each financial institution should aim to maintain a function of compliance and monitor rules of compliance, regulations and policies. The objective must be to set and enforce a clear line of accountability and responsibility. Such practices will lead to developing mechanisms that will align with the interest of managers and shareholders, leading to increased control of the financial institution (Gompers et al., 2003).

When organizational structures deviate from their mainstream conventional principles, the agency relationships and corporate governance (CG) issues become more complex (Kapopoulos and Lazaretou, 2007; Hu and Izumida, 2008). Relevantly, two tenets of the Islamic financial system (IFS) comprise solid governance and implanted moral values. The moral responsibility and ethical sense in Islamic banks (IBs) are anticipated to reduce agency-led implications such as lowering necessary risk-taking actions (Alam et al., 2020). Unlike conventional banks that permit managers to get involved in earning countless profits (Ramchandran et al., 2017), it is least encouraged in organizations operating with Islamic moral and/or ethical principles (Ha-Brookshire, 2015). A Sharíah supervisory board (SSB) is incorporated in Islamic financial institutions (IFIs) which acts as a supplementary but vital element in their CG process (Nomran and Haron, 2019). In conformity with Shariah principles to reduce the management's opportunistic behaviour, the SSB acts on behalf of stakeholders and carries out the responsibility of certifying and monitoring all financial contracts and bank activities (Abdesalam et al., 2016).

Some of the previous studies have focused on multilayer and dual internal governance structures that affect the performance of Islamic banks (IBs) and the SSB system (Mohammed and Muhammed, 2017); CG and earnings management nexus in the Islamic banking system (Abdesalam et al., 2016); and impacts of CG on the performance of IBs (Mollah and Zaman, 2015; Nomran and Haron, 2019). However, empirical research on Shari ah governance (SG) with respect to agency theory using a sample of the Middle Eastern IBs is very limited, and any previous study using such a sample from the Kingdom of Saudi Arabia (KSA) can hardly be found.

Given the above backdrop, the major aim of this paper is to examine the agency relationships in the specific context of Islamic banking operations in the KSA and hence make an important contribution to fill in the above-mentioned gaps in the literature. More clearly, this study will scrutinize the governance issues facing IBs in the KSA and their effectiveness in mitigating problems associated with agency aims, and hence develop an understanding of the distinctiveness of agency theory in the Islamic banking context. By making a detailed examination of the operations of IBs and their current practices, the study will build a theoretical base, which can then be used to overcome the challenges faced in the application of the agency theory in the context of Islamic financial institutions (IFIs). Further contribution of this study is made by investigating the impact of governance practices on institutional performance.

The major aim of this paper is addressed by accomplishing four specific objectives:

(1) to scrutinize the application of the agency theory in Islamic banking operations in the KSA;

(2) to throw light on the exclusivity of the agency problem in the Islamic banking industry arising from the duty of managers to abide by the Sharíah and separate cash flow and management rights for account holders;

(3) to perform an empirical examination of the governance practices and regulatory framework of IFIs in managing the agency issues, operations and performance; and

(4) to develop a substitute model of governance practice to address the traditional and exclusive agency issues in order to secure return on investment, safeguard the interest of account holders and, at the same time, uphold Sharíah principles. 
The paper is organised in five sections. The second section conducts a literature review of agency issues in the Islamic banking context and presents an overview of the banking sector in the KSA. Section three presents the research methodology used in this research. The next section highlights the empirical results. Lastly, the fifth section draws the conclusion and discusses implications for further research.

\section{Shariahah governance in Islamic banking}

\section{Literature review}

Shariah governance issues

The Accounting and Auditing Organization for Islamic Financial Institutions (AAOIFI) has issued seven standards on the SG of IFIs. It has also issued several guidelines to members of the SSB to ensure members' independence and limit the number of cross-memberships. These are essential areas of SG that demand ample consideration from Islamic finance regulators with regard to accountability, transparency and compliance with Sharı́ah principles. These are also important for encouraging public support on the etiquette and sanctity of business processes of IFIs.

In the matter of periodic review of compliance in $\mathrm{SG}$ procedures, the following steps are adopted: review procedure planning, executing the review procedures along with the working paper preparation, and lastly, documentation stages in which conclusions and reports should be presented to the shareholders (AAOIFI, 2017).

\section{Agency issues in Islamic banking}

According to Grassa (2013), the Sharîah governs all aspects of Islamic banking and financial institutions and adds value to the prevailing CG composition of IBs. Consequently, compliance with the Sharīah requires that specific $C G$ principles be applied within the Islamic banking system. The participation of SSB members in the CG pursuits of an IB gives rise to some unique issues, such as confidentiality, competency, independency, consistency and disclosure. Grassa et al. (2018) further add transparency and reputation in the list of issues that arise due to the involvement of SSB members in the IB's CG system. It may be noted that SG in the matter of disclosure and reporting refers to the communication of Sharîah information to all concerned stakeholders (AAOIFI, 2017).

The Qur'ān prohibits ribā (interest), gharar (uncertainty), maysir (gambling) and industries such as those related to pornography, pork products or alcoholic beverages, and these requirements must be taken into account by the SSB members and IBs' practitioners in order to comply with Islamic jurisprudence. Furthermore, SSB members ought to know the details of financial products to ensure the compliance of IFIs and other regulated bodies (Sole, 2007). In their empirical study on principal-agent conflicts and risk-taking behaviour of IBs, Fayed and Ezzat (2017) indicated that the conflicts between the principal and agent are conspicuous in both IBs and conventional banks mainly due to the contrasting and statistically significant effect of the rights of shareholders on risk-taking behaviour. Furthermore, they found that the conflict between the principal and agent is innate in conventional banks with regard to their impact on performance.

Zainuldin et al. (2018) in their study critically examined the agency theory from the perspective of IBs and integrated ethical considerations within a principal-agency setting. They found that SG rooted in IBs' business activities enables them to give more importance to ethical issues as compared to conventional banks. This also implies that IBs are less likely to have agency problems as compared to conventional banks.

To address the agency issues, financial institutions have adopted different governance systems (Beasley, 1996; Bebchuk et al., 2004; Nomran and Haron, 2019; Nawaz et al., 2021). The problems associated with agency in Islamic banking operations call for a separate investigation. There are several reasons for this. The first is due to the direct relation between 
IJIF

14,1

92

the rabb al-māl (financier) and the mudarizb (entrepreneur) in banking operations, which essentially makes a distinction between Islamic and conventional operations by widening the partition between ownership and control in the underlying agency theory. An important source of separation arises from the fact that IBs' administrators have to maximise the value of investments to shareholders in a Shariah-compatible approach (Archer et al., 1998). Moreover, the contracts between the bank and the account holder require the bank to share only profits, and not the losses or risks (muda arabah account), thereby preventing the account holder from intervening in fund management. This might provide an opportunity to IB managers to gain personal benefit, which is detrimental to the interest of account holders (Karim and Archer, 2002). Therefore, it is essential to ensure an organizational structure which separates the cash flow rights of account holders and their controlling rights.

Secondly, considering the phenomenal growth of IFIs, studies examining agency dynamics in this industry are of paramount importance. Islamic banking operations have been introduced in over 50 countries, spanning both Muslim and non-Muslim nations. It is estimated that there was an increase in the aggregate worth of IFIs from US $\$ 2.19 \mathrm{tn}$ in 2018 to US\$2.44tn in 2019 (Standard and Poor's, 2020). The Islamic financial services industry continues to grow at $11.4 \%$ on a year-on-year basis, and it maintained its growth momentum in 2019. This growth was noted to be mainly driven by significant improvements in the Islamic banking and capital market segments (IFSB, 2020). More importantly, even during the global economic downturn, the Islamic financial services industry managed to register a positive albeit slower growth rate than the year ending 2018.

In the context of the KSA, the banking sector deposits (both conventional banks and IBs) registered a $2.9 \%$ growth in 2019 (IFSB, 2020). On the contrary, IBs observed a $2.3 \%$ growth in their deposits in the same year, alongside a $2.4 \%$ growth in their assets, resulting in an overall $0.91 \%$ growth rate of the banking sector in the KSA in 2019. Like their conventional peers, IBs in other Gulf Cooperation Council (GCC) nations such as Bahrain, Kuwait, Qatar and the United Arab Emirates (UAE) saw slow balance sheet growth expansion in the financial year 2018. The growth in deposits in the GCC is noted as follows: Kuwait (4.2\%), Qatar $(1 \%)$, the KSA $(6.2 \%)$ and the UAE $(4.2 \%)$. This growth in deposits has happened for the first time in the last five years (Standard and Poor's, 2020).

Thirdly, while published studies (Hassan and Chachi, 2007; Saffieddine, 2009; Alam et al., 2020) shed light on several issues confronting IFIs and propose possible mitigating mechanisms, very few of those have examined the agency issues empirically. Published reports by Choudhury and Hoque (2006), Saffieddine (2009), Nomran and Haron (2019), Alam et al. (2020), among others, hinted at the existence of some intensified agency issues in IBs but did not address the challenges faced by the industry. In the context of the KSA, no such studies on agency dynamics at IFIs have been observed.

\section{The banking sector in the KSA}

Regulatory bodies: The KSA has 12 banks. Three of them are full-fledged IBs and the remaining nine are conventional banks with Islamic wings. Two main regulatory bodies oversee financial institutions in the Kingdom, notably the Saudi Arabian Monetary Agency (SAMA) and the Capital Market Authority (CMA).

Since its establishment in 1952, SAMA has been playing a vital role in the establishment and advancement of the Kingdom's financial system. Its major functions include issuing the Saudi Riyal (SAR), the national currency of the KSA; working as the government's banker; regulating commercial banks; overseeing the foreign exchange reserves of the Kingdom; implementing monetary policies to ensure the stability of exchange rates; fostering growth and safeguarding the soundness of the financial system, among others.

In 2003, the CMA was officially established under the Capital Market Law, pursuant to Royal Decree No. M/30. This is a public institution with complete financial, legal and 
governmental sovereignty, reporting directly to the Crown Prince and Deputy Premier of the Kingdom. The core responsibilities of the CMA are to control and develop the capital market of the Kingdom, formulate and/or amend rules and regulations from time to time, and implement the Capital Market Law that aims to provide a conducive investment environment.

The evolution of Islamic financial products: The Al-Rajhi Investment Company first introduced Islamic financing through murābahah (cost plus mark-up) operations in 1985. Starting its operations from Riyadh, the Kingdom's capital and holding strong Islamic values, Al-Rajhi acted as a foreign exchange provider and soon gained a reputation as a leading provider of Islamic financial services in the Kingdom. As of financial year 2017, Al-Rajhi retained its prominent position in the country's banking sector, recording a $15.4 \%$ share of the total banking assets in the Kingdom (Al-Rajhi, 2017).

Based on muräbahah transactions, the first Islamic mutual fund (International Trade fund) was introduced by the National Commercial Bank (NCB) in 1987. By mid-1990, payroll disbursement of employees was made through banks, and this measure paved the way for enhancing financing operations and reducing risks of default. During this period, for the first time, the NCB developed equity guidelines for Shariah compliance. This was a major breakthrough, as global index providers began to adopt these guidelines.

Recently, in the capital market, the NCB brought its total assets under management - both local and international - to US\$32bn as at financial year 2017. The NCB has gradually positioned itself as one of the biggest Sharíah-compliant commercial institutions globally. In 2017, the NCB emerged as the only Saudi partner for the issuance of government sukuk, which amounted to US\$9bn (NCB, 2018).

In 1999, the inter-bank transfer system (SARIE) was introduced to further reduce operational risk and to facilitate settlements, inter-bank transfers and clearance operations. In 2001, an innovative Islamic financial tool called Tayseer (which means facilitation) was introduced to directly provide liquidity to customers who avail of loans in a Sharíahcompatible model, based on the principles of murābahah.

Until recently, 12 banks offer Islamic products and over 75 Islamic mutual funds operate in the Kingdom (NCB, 2018). A growing number of customers demand that IBs provide evidence of Shariah compliance in all their banking and investment operations. Most customers prefer Islamic banking and financial services, whereas a relatively smaller segment opts for traditional banking when the former is not available (Hasan, 2010).

\section{Research methodology}

For this study, a survey comprising 38 questions was developed and sent to the 12 banks that offer either partial or full-fledged Islamic banking services in the KSA on 12 November 2019. The purpose was to investigate the Islamic banking practices and their efficacy in resolving agency issues. The survey addressed multiple issues such as consciousness of $\mathrm{CG}$ principles, effectiveness of the Board of Directors (BOD), effectiveness of the SSB, the rights of Islamic account holders (IAHs), auditing, and precision and clarity of financial reporting. Besides the survey, senior IB-administrators in the KSA were interviewed in order to extract necessary information on $\mathrm{CG}$ practices in IBs.

To examine the effect of CG on Islamic banking performance, the study followed an approach similar to the computation of the Gov-index by Gompers et al. (2003) and the Govscore by Brown and Caylor (2004) and Saffieddine (2009) to establish a quantitative index of CG. This index computes and aggregates value based on the following criteria:

(1) separating the positions of the Chief Executive Officer (CEO) and the Chairman;

(2) functioning of an audit committee;

(3) nominated members of the CG committee; 
IJIF

\section{4}

(4) operating a code of CG;

(5) separating the internal control function from internal audit departments;

(6) making periodic disclosure of information to the public;

(7) reporting to the shareholders by external auditors;

(8) having representatives of IAHs on the board;

(9) shareholders appointing the SSB; and

(10) provision for reporting by SSB to the shareholders.

These criteria have been identified by numerous published studies and are considered reflectors of sound CG (Anderson et al., 2004; Brown and Caylor, 2004; IFSB, 2005a; Saffieddine, 2009).

As mentioned above, data regarding CG issues was collected from 12 IBs in the Kingdom. For each bank, one point was given in the index for each of the existing principles of CG. Based on the outcomes, the overall mean value of the CG disclosure index by dimension and an overview of the correlations between these variables are highlighted in Tables 1 and 2 .

Using the mean values, the Islamic banking operators in the KSA are divided into two groups: high and low governance groups. Within the former group, banks have a higher governance index value while those in the lower group have lower index values. A number of performance measures were computed for each of the groups within an institution to assess the linkage between CG and its accomplishments. These processes included indicators of the operating performance and size, i.e. employee size, asset values, revenues earned and net profit growth year-over-year during the period of study. The other measures included were indicators of stock performance and appraisal comprising market capitalization, 12-month and 6-month index-adjusted returns, price-to-earnings ratio $(\mathrm{P} / \mathrm{E})$ and price-to-book-value ratio $(\mathrm{P} / \mathrm{BV})$.

\section{Analysis and discussion}

Table 1 reports the overall mean value of the CG disclosure index (CGDI) by dimension. It shows the CGDI score of $51.8 \%$, indicating that the CG disclosure index is just above the average. Looking at the different dimensions, the table also highlights that the components of the board structure and SSB are higher with scores at 62 and $69 \%$ respectively, whereas audit committee, transparency and disclosure presented lower scores in the CGDI.

Table 2 provides an overview of the correlations between the variables, as listed in the research methodology section above.

\begin{tabular}{lc} 
Dimension of corporate governance & CGDI (\%) \\
\hline Board structure & 62 \\
Risk management & 53 \\
Transparency and disclosure & 46 \\
Audit committee & 45 \\
Shariah Supervisory Board (SSB) & 69 \\
Investment account holders & 36 \\
Overall index & 51.8
\end{tabular}

Corporate governance disclosure index (CGDI) by dimension 


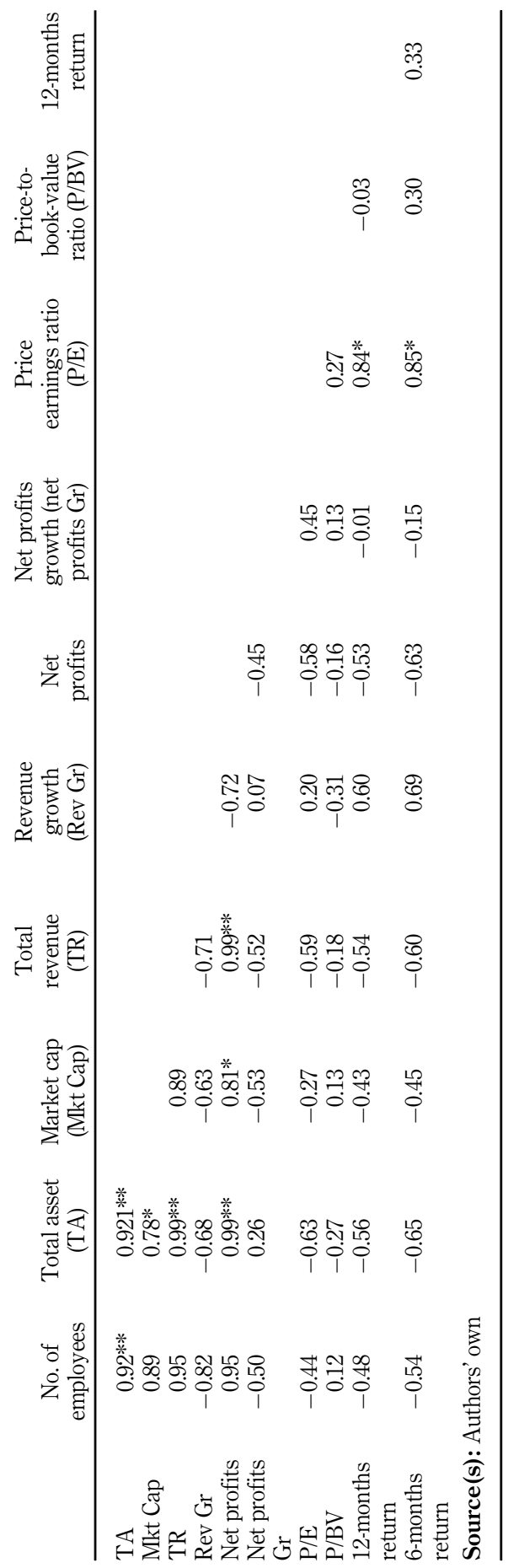

Shari`ah governance in Islamic banking

95

Table 2. Correlations 
IJIF

14,1

Seven executives and five members of the SSB responded to the primary survey. Table 3 highlights the organizational features of the sample. For example, the mean score of the sample in terms of number of employees is 1,361, the mean book value of assets is SAR139.11m and the mean net profit is SAR2.60m.

\section{Development of governance criteria}

In the KSA, there are no separate laws for IBs. All IBs therefore conform with the general laws that are pertinent to conventional banks; however, all conventional banks in the KSA have separately maintained Islamic banking windows. Their assets and accounts are not mixed with their conventional banking assets and accounts in order to remain within the legal regulatory environment. Furthermore, additional standards and regulations are enforced when necessary. Zaher and Hassan (2001), Choudhury and Hoque (2006) and Hassan and Chachi (2007) have emphasized the responsibilities of bank administrators and the value of governing policies and procedures that recognise the importance of Islamic banking services. All these studies observed the central bank of Saudi Arabia's adoption of specific measures to manage agency issues and to protect the interests of IAHs. The SAMA focuses on implementing the regulations to safeguard the returns of IAHs and resolve the exclusive agency issues faced by IAHs.

Table 4 lists the laws that presently regulate the functions of IBs in the KSA. A thorough examination of these regulations provides a fascinating understanding of the interface between agency issues and Islamic banking functions. In the KSA, IAHs are given a superior amount of security, enabling their risk levels to approach those of traditional bank depositors, rather than that of investors. However, only restricted investment accounts, which earn safe returns are permitted. These differences reveal supervisory disagreements between Sharíah law and the conventional financial markets, largely because Sharíah law forbids the receipt of fixed returns on money or interest of all types. Therefore, the legal guidelines discussed above may be useful in preventing the exploitation of IAHs' rights. Manipulations, if any, in the rights of the account holders may lead the IBs to depart from their main principles of risk-and-return sharing, suggesting the possibility of incongruities between principles and practice.

Studies of Chong and Liu (2009) mention that the actual practices of most IBs deviate frequently from those required by the Shari ah codes. For instance, some IBs are claimed to have fixed payment arrangements (muräbahah) in place, disguised as profit-loss sharing mechanisms (such as mudärabah and mushärakah) because of the agency problem. In this regard, one of the appropriate ways to ease agency difficulties is for an organisation to have a full disclosure policy. This would contain information on how the capital is managed, the purpose of the principal and agent, and the present performance of the organisation.

Another issue is the lack of efficient information sharing between the contracting parties. Extensive disclosure of data from the entrepreneur (agent/mudarib) that administers the fund on behalf of a fund provider (principal $/ r a b b$ al-māl) can help to lessen distortion and assist in taking decisions. Some of the methods that may be undertaken to prevent asymmetric information are: adoption of compatible incentive contracts, application of both sector and financial screening and supervising processes, implementation of Islamic social learning activities and adoption of Islamic codes of behaviour (Abalkhail and Presley, 2002).

Table 3.

Organizations' characteristics

\begin{tabular}{lrcr}
\hline & Mean & Minimum & Maximum \\
\hline Number of employees & $1,360.86$ & - & $4,554.00$ \\
Asset values (in SAR m) & 139.11 & 43.32 & 307.71 \\
Net profit (in SAR m) & 2.60 & 0.50 & 6.80 \\
Source(s): Authors' own & & & \\
\hline
\end{tabular}


Items in regulations applicable to financial institutions

Banking system types

Banking laws

Unrestricted investment account holders

(UIAH)

Disclosure requirements regarding

investment accounts

Accounting

Capital adequacy

SSB terms of reference

Composition of SSB

SSB decision making

Appointment and dismissal of the SSB

Criteria to determine whether SSB is fit and proper

Centralized SSB (higher Sharia ah authority)

Compensation committee (required versus encouraged)

Nomination committee (required versus encouraged)

Independent and non-executive board

members (required versus encouraged)

Source(s): Grais and Pellegrini (2006b), El-Hawary et al. (2007).

Dual

laws

Not specified

Not specified

By majority vote

Not specified

Not specified

Encouraged

Encouraged

Encouraged
Pattern of implementation of laws in the KSA

The operation of Islamic banks in line with the governing

Restricted investment accounts are only allowed having a low risk application and generating safe results

No disclosure requirements developed

AAOIFI's set of guidelines are complied by SAMA. However, the international accounting Standards (IAS) are also

officially required to be maintained

Not less than three qualified Muslim members

Centralized SSB does not exist

Table 4.

Regulations implemented in the KSA

The above-mentioned observations suggest that the operations of IBs raise questions regarding the agency theory. The rules set by SAMA to ensure the yields of IAHs and avert agency issues may compel IBs to deviate from complying with the Shariah, the very reason for their existence. This question leads to the following proposition:

Theoretical Proposition 1. Regulatory and capital issues under the conventional system are not consistent with Sharíah law. Financial institutions governed by the conventional system often contradict Islamic banking principles.

As discussed, separate laws do not exist for IFIs in the KSA, and additional guidelines and rules have been issued corresponding to the guidelines proposed by AAOIFI. Although banking and finance regulations in the KSA are closer to the Islamic essence, they do not ensure a minimum rate of return to IAHs. Therefore, to protect the interest of IAHs, SAMA is undertaking efforts to ensure IBs comply with governance standards. The SSB is expected to enforce strict and precise abidance with the Shariah. These regulations are meant to safeguard the rights of the IAHs. At the same time, they rule out the practice of interest and call for profit-and-loss sharing as per the principles of Islamic finance. These findings lead us to the next proposition:

Theoretical Proposition 2. Some distinctive propositions in CG under Sharíah law allow IFIs to deal effectively with morally unacceptable behaviour, alleviating the need for agency mitigating mechanisms that are contradictory to Shariah principles. 
IJIF

14,1

98

Table 4 highlighted that IBs in the KSA are not required to establish audit committees, or compensation committees, although some might do so. The lack of directives gives room for agency-related challenges, arising from lack of sufficient control during enactment of regulatory requirements, nomination of managers and directors, determination of their salaries and implementation of the financial reporting process. Furthermore, SAMA does not require IFIs to nominate either independent or non-executive directors on their boards. In fact, the enactment of $\mathrm{CG}$ regulations falls under the responsibility of the central bank, and further action is therefore required by the central bank for IFIs to conform and carry out CG mechanisms in their organizations.

Corporate governance practices and mitigation of agency issues

Commitment of board members in the governance system: Referring to the CG rules issued by the IFSB, Hassan and Chachi (2007), Saffieddine (2009) and Nomran and Haron (2019) argue that a CG policy framework that matches the features and characteristics of IFIs must be incorporated; otherwise, it may lead to agency problems.

Responses from the survey carried out in the present study reveal that a majority of IBs in the KSA are aware of the significance of incorporating sound governance practices. For example, over $85 \%$ of the surveyed IBs have adopted the principles of the Basel Committee on Banking Supervision (BCBS) or the Organization for Economic Cooperation and Development (OECD). Furthermore, $89 \%$ of IBs have either developed their own governing principles or are in the process of developing them. The results of the questionnaire suggest that most IBs observe the governance principles and have set up strong corporate principles to safeguard the benefits of stakeholders as the primary responsibility of their CG practices.

Among the GCC countries, Saudi Arabia and Qatar seek to safeguard the benefits of IAHs and alleviate the unique agency issues that they face by enforcing on banks the requisite of ensuring the returns on IAH investments. This study supports the study done by Saffiedine (2009), which stated that a close analysis of these regulations makes the interface between agency problems and Islamic finance processes clearer. In these countries, IAHs are accorded a high level of security, thereby minimising risks to investors. The KSA only permits restricted accounts that ensure safe returns to investors. In Qatar, authorities require IFIs to consider unrestricted IAHs in a manner similar to those of conventional depositors by paying them a steady rate of return (Safieddine, 2009).

The survey responses in this study reveal that $67 \%$ of IBs have assigned the process of monitoring to a CG committee; however, none of them have given any specific responsibility to the designated CG officer to carry out his/her defined duties. Fifty-five per cent of the surveyed institutions also reveal that they do not have any established role of a governance administrator. In this situation, the monitoring task is handed over to internal audit activities and interior committees.

The lack of a specific governance group goes against the suggestions of the IFSB that strongly emphasize the formation of such a composed committee with pre-specified tasks. However, the SSB units of the IBs monitor the Shariah compliance of the banks. Ninety-eight per cent of the surveyed institutions considered that they could improve governance using internal mechanisms relating to the involvements of shareholders, the responsibilities of the $\mathrm{BOD}$ and roles of the inner control groups.

Responses of the survey reflect that the majority of IBs have not provided due consideration to introduce a practice of "Shariah-compliant corporate governance" in their institutions or develop a consciousness of governance issues. Results reveal that $43 \%$ of the IBs do not train key personnel on topics related to SG. Since the IFSB (2005b) and the BCBS (2006) require the board members to have a discernment of their responsibilities in CG, the scenario does not meet the requirements of the CG regulations issued by the IFSB and the BCBS. 
The role of the BOD: In an IFI, the board shoulders prime responsibilities of effective oversight over the management, protecting the rights of the shareholders and setting overall strategic policies in the best interest of the institution (Chapra and Ahmed, 2002). The ramification of the lack of training, as revealed above, is that the BOD has only a vague idea about its major responsibilities. The low percentage of responses during the survey can be reflective of this problem in the management style of the BOD. The sample surveyed reveals that none of the IBs takes into consideration the tactical responsibility of the board in establishing the direction in general, or mission or vision. They had the following understanding of a director's starting responsibility:

(1) to ensure conformity with policies and guidelines ( $89 \%$ of the sample).

(2) to take care of the interests of shareholders ( $6 \%$ of the sample).

(3) to manage conflicts of interest among stakeholders (3\% of the sample).

(4) to supervise the management ( $2 \%$ of the sample).

The complex financial operations in IFIs warrant the establishment of multifaceted relationships with different stakeholders and managers. In order to ensure that IBs conform to fundamental governance principles as an essential responsibility of the BOD, their structured roles and the number of board meetings should be directed towards achieving this basic goal. In the sample of this study, the least number of board members is recorded to be 9 and the mean is 10.20 . However, there is a common consensus that non-executive directors demonstrate superior performance in securing the autonomy of governance decisions (from the influence of the management) and in safeguarding the interests of investors (Chapra and Ahmed, 2002). Earlier, Beasley (1996) suggested that the sovereignty of a board corresponds to a fall in financial mismanagement. Unfortunately, information about outside/nonexecutive directors was not available for the sample selected in this study.

The surveyed respondents shared their understanding that all IBs have the necessary knowledge and experience to run their activities in an effective manner. The survey finds that IBs hold their meetings at regular intervals, and they are bound to publicly disclose the compensation for their services. The results show that the surveyed banks have BODs that govern these institutions through the establishment of policies with a target of achieving organizational objectives and mitigating agency problems.

The role of the SSB: Shariah compliance is the distinctive characteristic of IFIs. These institutions are entrusted with investing their funds according to Sharíah principles. All IBs in the sample of this study have an independent SSB that is composed of four to five members. This is in alignment with AAOIFI's prerequisite of having at least three Shariah board members.

In this study, $42.9 \%$ of the IBs use their general assembly to appoint SSB members, and this result corroborates the findings of Grais and Pellegrini (2006a). However, in the other $57.1 \%$ of the surveyed banks, the BOD appointed the Sharıah members.

Eighty-three per cent of the surveyed banks also show that SSB members have Islamic banking experience while $28.6 \%$ disclose that they have prior working experience in conventional banks and this is deemed useful. However, as Grais and Pellegrini (2006b) emphasized, Shari ah scholars are also expected to be knowledgeable about Islamic laws. The surveyed respondents also reveal that the SSB members were not entitled to be board members (to act as directors) in the absence of owning bank shares. This is in conformity with AAOIFI principles and regulatory standards.

The survey further reveals that the SSB members meet on a quarterly basis and that final decisions are made through voting. The SSBs of $71.5 \%$ of the IBs report to both the BOD and shareholders, while the SSB of $28.5 \%$ of the IBs report only to the BOD. All surveyed IBs treat the SSB rulings as obligatory. 
IJIF

14,1

100

In summary, a majority of the surveyed respondents indicate that the SSBs are well established with effective composition, autonomy and enforcement of decisions. They provide positive and independent advice on Shariah-compliant products, avoiding conflict of interests and agency problems.

Investment account holders (IAHs): In terms of the possible conflicts of interest of organizational management and stakeholders, issues regarding IAHs should be addressed within the governance framework of IFIs. The survey outcomes highlight that the rights of shareholders and customers are given priority. The survey results also portray that, although the IFIs have a clear perception of the rights of IAHs, they do not give substantial weightage to the practice. For example, an IAH cannot be a member of the board, and they cannot take part in making management-level decisions. Thus, IAHs cannot monitor their investments or communicate with shareholders about their needs and concerns, which poses serious agency problems for IAHs, sometimes exposing their investments to excessive risks.

Under Shariah compliance, even though IAHs can enjoy cash flow rights, they cannot control investments, as these are invested and managed by the banks. A survey on the preferences of Islamic banking customers reported that account holders are interested in participating in the banks' strategy-level management (Chapra and Ahmed, 2002). This is indicative that an opportunity for IAHs to be represented on the board would boost their confidence in their investments and make them enthusiastic in making further investments of their funds. However, even though the involvement of IAHs in the monetary mechanism may be advantageous, it may raise a possibility of conflict of interest with shareholders when each group becomes active to safeguard self-interests. Some areas of conflicts may pertain to the risk appetite, profit equalization reserve, etc., which are potentially strong reasons for preventing the IAH-representation on the board. Such observations offer a backdrop for making the theoretical proposition below:

Theoretical Proposition 3. IFIs face incompetence issues and endeavour to develop a desirable compromise between the cash flow and rights of control of IAHs, alleviating disputes between shareholders and investors.

Audit and control - implications of governance practices and mitigation of agency issues: All surveyed IBs have internal control departments, reporting on a quarterly basis to the BOD. This reflects the availability of a method for the BOD to manage the material risks under strict supervision. In order to avoid conflicts and ensure better compliance with Shariah principles, a member of the internal control department cannot serve on the SSB. In addition, the responses show that $57.1 \%$ of the surveyed IBs have an understanding that internal control tasks are meant to make sure that all rules and regulations, including Shariah principles, are conformed with. This procedure complies with the suggestions of AAOIFI (1996, 1997).

According to $16.7 \%$ of the surveyed banks, the banks' departments of arbitration are responsible for mitigating conflicts of interest. $57.1 \%$ of the surveyed banks have not come across any issues in collecting correct information about the quality of the projects they have invested in, and this enables the IBs to regulate credit risks (IFSB, 2005a). The possibility that Islamic banking operations may expose investors to odd risks is a noteworthy observation. In such a scenario, the investors would be exposed to credit risk without any indemnity. According to Sundararajan and Errico (2002), within these contracts, the clients themselves would be the fund managers.

As effective as these practices may sound, insofar as building up clear pathways for risk management and conformity with the system, responses by the IBs surveyed indicate that these have not been fittingly addressed. While $79 \%$ of them join the internal control and inward evaluating capacities, only $13 \%$ concur that the internal control division ought to be 
responsible for ensuring the accuracy of financial transactions. This implies that the surveyed IBs do not properly audit the financial reporting methods.

The survey results reflect that the IFIs do not place much emphasis on establishing audit committees. Although audit committees are not mandatory for the IFIs, they are advised to incorporate governance, compensation and audit committees. This is the reason for the inability to validate the correctness of the information given by the IFIs. Such a situation develops agency problems among the IBs, their shareholders and the depositors who claim shares in the profits.

According to this study's findings, $33.3 \%$ of the surveyed IBs adhere to the International Accounting Standards (IAS), 33.3\% embrace the AAOIFI standards and 16.7\% adopt both standards. This may emerge to be an important matter of concern. This, however, indicates that some inconsistency may occur in certain transactions in specific Islamic financial operations that are not covered by the IAS. This inconsistency may compel some IBs to embrace the above two standards. Inconsistent standards and the lack of an audit committee and an auditing procedure make the financial reports less trustworthy. Thus, investors cannot make a real comparison of the performance of IBs. This may introduce additional agency problems, where managers may exercise their discretion regarding unrestricted investments. Such practices are encouraged when control systems, as proposed by Karim and Archer (2002), are not followed to observe the financial reporting system.

According to the findings, $42.9 \%$ of the surveyed IBs reveal that their external auditors report to the shareholders. It is believed that reporting bridges the gap between any agency problem that may arise between the banks and their shareholders. Internal monitoring of financial reporting improves the performance of an IB. However, there might still be a possibility of a conflict between depositors and account holders. For example, as Archer $e$ t al. (1998) emphasized, the capacity of an external audit must be stretched to encompass all muda arabah (trust financing) funds, and IBs must put in place an appropriate accounting system that will cover auditing of cost allocations and profit-and-loss-sharing ratios.

Transparency and disclosure: According to IFSB (2005b), the disclosure of information should be precise. The option to access information is considered a good governance practice as it enables stakeholders to evaluate the IBs' performance in a better way and hence deduce wise investment decisions. According to the sample in this study, $14.3 \%$ of the IBs disclose information about themselves, including governance and financial performance, through virtual means. $71.4 \%$ of the surveyed banks reveal that their disclosure of information is made through their annual reports, and $14.3 \%$ claim that they make accurate disclosure to stakeholders.

The other information disclosed by the surveyed banks includes the allocation and justification for profit distribution among account holders, the principles of $\mathrm{CG}$, risk control policies, the organizational chart and party-related deals, etc., and this practice follows the requirements of AAOIFI (Karim and Archer, 2002). However, some of the officers of the surveyed banks refer to any deficiency of disclosure as a vital issue that Islamic banking investors face. IBs preserve data related to the returns on the investments of IAHs. Thus, it is pertinent for the IAHs to appraise the accomplishment of their assessments and to supervise the management functions. Furthermore, some of these officers suggest that the managers would be tempted to take undue risks when the allocation of profits on investments is not revealed. The survey results imply that transparency in the investment accounts and CG should be enhanced to protect investors' rights. The survey results also draw attention to the need to minimize improper managerial behaviour.

\section{Effective governance and IFI performance nexus}

The survey outcomes on the nexus between the corporate governance index (CGI) and the performance of the IBs are highlighted in Table 5. The findings corroborate the previous studies' outcomes (e.g. Brown and Caylor, 2004) on CG in the context of conventional financial 


\begin{tabular}{llrrr} 
IJIF & Description & High & Low & Differences in means \\
\cline { 2 - 4 } 14,1 & Number of employees & $1,311.66$ & $1,331.97$ & -20.31 \\
& TA (in million SAR) & 139.03 & 307.31 & -168.28 \\
Mkt Cap (in million SAR) & $8,300.79$ & $2,700.52$ & $5,600.27$ \\
& Total revenue & 5.23 & 13.66 & -8.43 \\
$\mathbf{1 0 2}$ & Revenue growth & 0.26 & 0.03 & 0.23 \\
& Net profit & 6.83 & 2.60 & 0.23 \\
Net profit growth & 0.26 & 0.09 & 1.18 \\
Table 5. & 6-month return & 0.68 & -0.50 & 1.28 \\
The relationship & Price-to-earnings ratio & 0.30 & -0.98 & 14.07 \\
between corporate & Price to book ratio & 24.27 & 10.2 & 1.21 \\
governance index and & Note(s): The levels of significance for the difference in the means are denoted by: *** $(p<0.001)$ \\
performance & Source(s): Authors' own & & \\
\hline
\end{tabular}

institutions. Though the present study has a comparatively smaller sample with regard to the employee size and total assets, it seems that the surveyed institutions are performing within the desired efficiency level. It means that better-governed IBs enjoy higher levels of returns (in terms of profits, sales, etc.) and retain the earning potential for further growth, enjoying a higher market stake and/or value. For example, these banks have managed a larger market capitalization (SAR8,300.79m vs SAR2,700.52m of the poorly governed banks). In addition, their profits outstripped those of their poorly managed counterparts by SAR4.23m and recorded substantially greater annual increase in revenues and net profit. In terms of indexadjusted stock performance, the IBs with low CGI values have underperformed in the market, as mirrored by the 12 -month $(-50.10 \%)$ and 6-month $(-98.30 \%)$ stock returns. These results support earlier studies, such as Safieddine (2009).

Table 5 exhibits the outcomes of the nexus between the CGI and accomplishments of the surveyed IBs in the KSA. Using median value, the banks are clustered into two groups. Based on various appraisals for examining the above nexus, it is observed that the banks in the High CG group have the highest CGI values and those in the Low CG group have the lowest CGI values. The measures include the number of employees, total assets, market capitalization, total revenue, annual revenue growth, yearly net profits, net profit growth per annum, 12- and 6-month index-adjusted returns, price-to-earnings ratio $(\mathrm{P} / \mathrm{E})$ and price-to-book-value ratio $(\mathrm{P} / \mathrm{BV})$. In terms of the 12- and 6-month returns, the poorly governed banks have underachieved the well-managed banks by 118 and $128.11 \%$ respectively (significant at $p<0.001$ ). Moreover, the market investors seem to feature a higher value for the bettergoverned banks. Their $\mathrm{P} / \mathrm{E}$ and $\mathrm{P} / \mathrm{BV}$ ratios, i.e. 24.27 and 2.42 respectively, appear to be higher than their poorly governed counterparts, i.e. 10.20 and 1.21 respectively. All differences in the means of the high and low groups are statistically significant at $1 \%$.

As found by Saffieddine (2009), the analysis of the results casts doubts on the preferences of the IAHs when a compromise between securing better profits on their funds and a Shari ahcompliant investment under high CG is attempted. Chapra and Ahmed (2002) reported that the lack of conformity to Shariah principles limits the IBs' capacity to draw the attention of investors. A better formed regulatory framework with an equilibrium between idiosyncratic methods of governance and conformity with the Shariah principles may emerge to be more efficient in stimulating the flourishing of the Islamic finance industry. Thus, they will also be more effective, in contrast to the IFIs that establish mitigating processes to overcome agency issues but jeopardize the fulfilment of the Shariah requirements. In light of the above background, the following theoretical proposition is made: 
Theoretical Proposition 4. The distinctive governance models that provide opportunities for the safeguarding of IAHs and conform to the Shariah principles would be more successful than those operating entirely according to profit motives.

\section{Conclusion}

The study focuses on IBs as a proxy of the IFIs operating in the KSA. It draws attention to the exclusivity of the agency problems originating from the actions of managers (in accordance with the Shariah) and the partition between cash flow and the rights of control of IAHs. The study inquired into the influence of governance practices of these institutions for relieving agency problems and with respect to operations and accomplishments. The findings indicate that the majority of the surveyed IBs recognize the importance of and the justification for incorporating governance procedures. This is in agreement with the results of Safieddine (2009), who recommended some useful tools of governance that included the BOD, SSB and internal control departments - with required credentials and conducive structure - to alleviate agency issues. On the contrary, it is observed that shortcomings in the practical implications of governance still fail to resolve agency issues. However, a strict compliance is yet to be accomplished.

The outcomes of this research also highlight that the IBs with a superior value in the index of conventional and idiosyncratic governance systems appear to be more rewarding (in terms of profits, stock performance and stock valuations) than their counterparts with lower index values. This finding is also in agreement with a similar set of observations of Saffieddine (2009).

In consideration of the fact that there are only 12 banks operating in the KSA, of which only Al-Rajhi Bank, Al-Bilad and Alinma Bank are full-fledged IBs while the rest of the banks have Islamic wings, the information used and the responses received in this study were of limited nature. Likewise, the examination of the relation between CG and its accomplishments has been subject to a small sample of IBs in the KSA and constrained to a single year of performance metrics. Therefore, the results presented and analysed in this research are not entirely free from criticism. It is suggested that future studies must undertake in-depth analysis into the agency problems with respect to SG in the KSA. Present studies have not investigated these issues comprehensively. Future studies must examine SG issues in the KSA with larger data.

\section{References}

AAOIFI (1996), Standard on Islamic Accounting and Auditing No. 2: The Auditor's Report, Accounting and Auditing Organization for Islamic Financial Institutions, Bahrain.

AAOIFI (1997), Auditing Standard for Islamic Financial Institutions No. 4: Shari ah Supervisory Board: Appointment, Composition, and Report, Accounting and Auditing Organization for Islamic Financial Institutions, Bahrain.

AAOIFI (2017), 2017 Outstanding Year of Excellence and 107 Standards, Accounting and Auditing Organization for Islamic Financial Institutions, Bahrain.

Abalkhail, M. and Presley, J.R. (2002), "How informal risk capital investors manage asymmetric information in profit/loss-sharing contracts", in Iqbal, M. and Llewellyn, D. (Eds), Islamic Banking and Finance: New Perspective on Profit-Sharing and Risk, Edward Elgar Publishing Limited, Cheltenham, pp. 111-138.

Abdesalam, O., Dimitropoulos, P., Elnahass, M. and Leventis, S. (2016), "EM behavior under different monitoring mechanisms: the case of Islamic and conventional banks", Journal of Economic Behavior and Organization, Vol. 132 No. 5, pp. 155-173. 
IJIF

14,1

104

Al-Rajhi (2017), Annual Report 2007, Al-Rajhi Bank, Saudi Arabia.

Alam, N., Ramchandran, J. and Nahomy, A. (2020), "The impact of corporate governance and agency effect on EM-A test of the dual banking system", Research in International Business and Finance, Vol. 14 No. 1, pp. 1-24.

Anderson, R.C., Mansi, S.A. and Reeb, D.M. (2004), "Board characteristics, accounting report integrity, and the cost of debt", Journal of Accounting and Economics, Vol. 37 No. 3, pp. 315-342.

Archer, S., Ahmed, R., Karim, A. and Al-Deehani, T. (1998), "Financial contracting, governance structures, and the accounting regulation of Islamic banks: an analysis in terms of agency theory and transaction cost economics", Journal of Management and Governance, Vol. 2 No. 2, pp. 149-170.

BCBS (2006), Enhancing Corporate Governance for Banking Organisations, Bank for International Settlements, Basel.

Beasley, M.S. (1996), "An empirical analysis of the relation between the board of director composition and financial statement fraud”, The Accounting Review, Vol. 71 No. 4, pp. 443-465.

Bebchuk, L., Cohen, A. and Ferrell, A. (2004), "What matters in corporate governance?”, NBER Working Paper, available at: https://dash.harvard.edu/bitstream/handle/1/11224528/SSRNid593423.pdf;jsessionid $=$ D9396FC27655A3C1332F0517181BE348? sequence $=1$ (accessed 2 June 2021).

Brown, L. and Caylor, M. (2004), Corporate Governance and Firm Performance, Working Paper, Georgia State University.

Chapra, M.U. and Ahmed, H. (2002), Corporate Governance in Islamic Financial Institutions, Periodical Document No. 6, Islamic Development Bank, Islamic Research and Training Institute, Jeddah.

Chong, B.S. and Liu, M. (2009), "Islamic banking: interest-free or interest-based?", Pacific-Basin Finance Journal, Vol. 17 No. 1, pp. 125-144.

Choudhury, M. and Hoque, M. (2006), "Corporate governance in Islamic perspective", Corporate Governance, Vol. 6 No. 2, pp. 116-128.

El-Hawary, D., Grais, W. and Iqbal, Z. (2007), "Diversity in the regulation of Islamic financial institutions", The Quarterly Review of Economics and Finance, Vol. 46 No. 5, pp. 778-800.

Fama, E.F. and Jensen, M.C. (1983), "Separation of ownership and control", The Journal of Law and Economics, Vol. 26 No. 2, pp. 301-325.

Fayed, M. and Ezzat, S. (2017), "Do principal-agent conflicts impact performance and risk-taking behavior of Islamic banks?", Proceedings on the Middle Eastern and African Economies Conference, Vol. 19 No. 2, available at: https://ecommons.luc.edu/cgi/viewcontent.cgi? article $=1253 \&$ context $=$ meea (accessed 16 July 2020).

Gompers, P., Ishii, J. and Metrick, A. (2003), “Corporate governance and equity prices”, The Quarterly Journal of Economics, Vol. 118 No. 1, pp. 107-155.

Grais, W. and Pellegrini, M. (2006a), "Corporate governance and stakeholders' financial interests in institutions offering Islamic financial services”, World Bank Policy Research Working Paper, available at: https://www.researchgate.net/publication/23550055_Corporate_Governance_and_ Stakeholders'_Financial_Interests_in_Institutions_Offering_Islamic_Financial_Services (accessed 26 August 2021).

Grais, W. and Pellegrini, M. (2006b), "Corporate governance and Shari'ah compliance in institutions offering Islamic financial services", World Bank Policy Research Working Paper, p. 4053.

Grassa, R. (2013), "Shariah supervisory system in Islamic financial institutions: new issues and challenges: a comparative analysis between Southeast Asia models and GCC models", Humanomics, Vol. 29 No. 4, pp. 333-348.

Grassa, R., Chakroun, R. and Hussainey, K. (2018), “Corporate governance and Islamic banks' products and services disclosure”, Accounting Research Journal, Vol. 31 No. 1, pp. 75-89.

Ha-Brookshire, J. (2015), "Towards moral responsibility theories of corporate sustainability and sustainable supply chain”, Journal of Business Ethics, Vol. 145 No. 1, pp. 127-137. 
Hasan, Z. (2010), "Regulatory framework of Shari'ah governance system in Malaysia, GCC countries and UK", Kyoto Bulletin of Islamic Areas Studies, Vol. 3 No. 2, pp. 82-115.

Hassan, A. and Chachi, A. (2007), "Corporate governance of Islamic financial services in Brunei Darussalam”, Journal of Islamic Economics, Banking and Finance, Vol. 4 No. 1, pp. 30-51.

Hu, Y. and Izumida, S. (2008), "Ownership concentration and corporate performance: a causal analysis with Japanese panel data", Corporate Governance: An International Review, Vol. 16 No. 1, pp. 342-358.

IFSB (2005a), Guiding Principles of Risk Management for Institutions (Other Than Insurance Institutions) Offering Only Islamic Financial Services: Exposure Draft No. 1, Islamic Financial Services Board, Kuala Lumpur.

IFSB (2005b), Guiding Principles on Corporate Governance for Institutions Offering Only Islamic Financial Services (Excluding Islamic Insurance Institutions, Takaful and Islamic Mutual funds): Exposure Draft No. 3, Islamic Financial Services Board, Kuala Lumpur.

IFSB (2020), IFSB Stability Report 2020, Islamic Financial Services Board, Kuala Lumpur.

Kapopoulos, P. and Lazaretou, S. (2007), "Corporate ownership structure and firm performance: evidence from Greek firms", Corporate Governance: An International Review, Vol. 15 No. 2, pp. 144-158.

Karim, R.A. and Archer, S. (2002), Islamic Finance: Innovation and Growth, Euromoney Publications, London.

Mohammed, A.S.A.S. and Muhammed, J. (2017), "The relationship between agency theory, stakeholder theory and Shari'ah supervisory board in Islamic banking: an attempt towards discussion", Humanomics, Vol. 33 No. 1, pp. 75-83.

Mollah, S. and Zaman, M. (2015), "Shari'ah supervision, corporate governance and performance: conventional vs. Islamic banks", Journal of Banking and Finance, Vol. 58 No. C, pp. 418-435.

Nawaz, T., Hanifa, R. and Hudaib, M. (2021), "On intellectual capital efficiency and Shari'ah governance in Islamic banking business model", International Journal of Finance and Economics, Vol. 26 No. 3, pp. 3770-3787.

NCB (2018), Annual Report 2018, The National Commercial Bank, Saudi Arabia.

Nomran, N. and Haron, R. (2019), "A systematic literature review on Shari'ah governance mechanism and firm performance in Islamic banking”, Islamic Economics Studies, Vol. 27 No. 2, pp. 91-123.

Ramchandran, J., Ngete, Z., Martin, K. and Pizzaini, M. (2017), "Does corporate governance influence EM: evidence from Singapore”, Journal of Development Areas, Vol. 49 No. 3, pp. 263-274.

Saffieddine, A. (2009), "Islamic financial institutions and corporate governance: new insight", Corporate Governance, Vol. 17 No. 2, pp. 142-158.

Sole, J. (2007), "Introducing Islamic banks into conventional banking systems", IMF Working Paper No. 175, doi: 10.5089/9781451867398.001 (accessed 3 February 2021).

Standard \& Poor's (2020), "Islamic finance Outlook 2020 edition”, available at: https:/www.spglobal. $\mathrm{com} / \mathrm{ratings} / \mathrm{en} / \mathrm{research} / \mathrm{pdf}$-articles/islamic-finance-outlook-2020-edition (accessed 3 January 2021).

Sundararajan, V. and Errico, L. (2002), "Islamic financial institutions and products in the global financial system: key issues in risk management and challenges ahead”, IMF Working Paper WP/02/192, available at: https:/www.imf.org/external/pubs/ft/wp/2002/wp02192.pdf (accessed 3 January 2021).

Zaher, T.S. and Hassan, M.K. (2001), "A comparative literature survey of Islamic finance and banking”, Financial Markets, Institutions and Instruments, Vol. 10 No. 4, pp. 155-199.

Zainuldin, M.H., Lui, T.K. and Yii, K.J. (2018), "Principal-agent relationship issues in Islamic banks: a view of Islamic ethical system", International Journal of Islamic and Middle Eastern Finance and Management, Vol. 11 No. 2, pp. 297-311. 
About the authors

14,1

Abul Hassan, Ph.D., is an Associate Professor and Research Scientist II at the Interdisciplinary Centre in Finance and Digital Economy, KFUPM Business School, King Fahd University of Petroleum and Minerals, Dhahran, Saudi Arabia. His area of research interest is in digital transformation in banking and Islamic finance.

M. Sadiq Sohail, Ph.D., is a Professor at KFUPM Business School, King Fahd University of Petroleum and Minerals, Dhahran, Saudi Arabia. His recent research interest is in the area of corporate governance. He is a prolific researcher and has published over hundred articles in well-known journals. M. Sadiq Sohail is the corresponding author and can be contacted at: ssohail@kfupm.edu.sa

Md Mahfuzur Rahaman Munshi is pursuing his Ph.D. at Gloucestershire University, UK in the area of corporate governance.

For instructions on how to order reprints of this article, please visit our website: www.emeraldgrouppublishing.com/licensing/reprints.htm Or contact us for further details: permissions@emeraldinsight.com 